\title{
Cytogenetic characteristics of pikas Ochotona hyperborea and O. mantchurica (Lagomorpha, Mammalia) in the Amur River Basin
}

\author{
Irina V. Kartavtseva*, Alexey A. Vakurin, Andrey A. Lissovsky, \\ Liubov V. Frisman
}

\begin{abstract}
Most pikas of the genus Ochotona have clear cytogenetic differentiations; therefore, karyotype characteristics offer good diagnostic features in this group. The northern pika O. hyperborea is one of the most widely distributed pika species in the Russian Far East. Cytogenetic data on pikas from new localities from the Amur River Basin were obtained for elaborating on the species' identification. Chromosome staining showed that pikas from the Bastak Nature Reserve (Jewish Autonomous Region, Russia) differ from the previously studied $O$. hyperborea. In addition, chromosome morphology for O. hyperborea from the Bastak Nature Reserve and from the Soktahan Range in the Amur Region (Russia) was found to be slightly different. The variation found in the $\mathrm{C}$-stained chromosomes can be explained by the geographic reasons. The Manchurian pika $O$. mantchurica from the right bank of the Shilka River (Zabaikalskiy Territory, Russia) had diploid number of chromosomes $2 n=39$. This is an X0 karyotype variant with a single $\mathrm{X}$ chromosome that has been found in Ochotonidae for the first time.
\end{abstract}

KEY WORDS: pika, Ochotona, chromosome, C-staining, Ag-NOR staining.

Irina V. Kartavtseva [irina-kar52@rambler.ru], Institute of Biology and Soil Science, Far Eastern Branch of the Russian Academy of Sciences (FEB RAS), pr. Stoletiya 159, Vladivostok 690022, Russia; Alexey A. Vakurin [vakurin.ibss@mail.ru], Institute of Biology and Soil Science, FEB RAS, pr. Stoletiya 159, Vladivostok 690022, Russia; Andrey A. Lissovsky [andlis@zmmu.msu.ru], Zoological Museum of Moscow State University, B. Nikitskaya 6, Moscow 125009, Russia; Liubov V. Frisman [l.frisman@mail.ru], Institute for Complex Analysis of Regional Problems, FEB RAS, Sholom-Aleikhem Street 4, Birobijan 679016, Russia.

\section{Цитогенетическая характеристика пищух Ochotona hyperborea и O. mantchurica (Lagomorpha, Mammalia) бассейна реки Амур}

\author{
И.В. Картавцева, А.А. Вакурин, А.А. Лисовский, Л.В. Фрисман
}

РЕЗЮМЕ. Многие пищухи рода Ochotona обладают выраженной цитогенетической дифференциацией, поэтому характеристики кариотипа иногда являются хорошим диагностическим признаком для этой группы. На Дальнем Востоке России обитает один из наиболее распространенных видов пищух - северная пищуха O. hyperborea. Для видовой идентификации получены цитогенетические данные о пищухах из необследованных ранее локалитетов в бассейне реки Амур. Пищухи из заповедника «Бастак» (Еврейская Автономная область) отличаются от раннее изученных $O$. hyperborea по C- и Ag-NOR окраскам хромосом. Также обнаружены отличия в морфологии хромосом O. hyperborea из заповедника «Бастак» и хребта Соктахан в Амурской области от опубликованных ранее данных. Обнаружена изменчивость С-окрашивания хромосом, которая возможно носит географический характер. Маньчжурская пищуха O. mantchurica с правого берега реки Шилка (Забайкальский край) имела нетипичное диплоидное число хромосом равное 39 . Такой Х0 вариант кариотипа с одной X-хромосомой у пищух семейства Ochotonidae обнаружен впервые.

КЛЮЧЕВЫЕ СЛОВА: пищуха, Ochotona, хромосомы, С-окраска, Ag-NOR окраска.

\section{Introduction}

According to recent reports (Sokolov et al., 1994; Lissovsky, 2012), only one pika species — the northern pika Ochotona hyperborea (Pallas, 1811) — inhabits the Russian Far East. This species is distributed from the north of taiga zone of the Polar Urals to the Pacific

* Corresponding author coast, including Sakhalin and Hokkaido. Another closely-related species that inhabits the basin of the Amur River is the Manchurian pika O. mantchurica Thomas, 1909 (Lissovsky, 2005; Formozov et al., 2006; Lissovsky et al., 2007, 2008; Formozov \& Baklushinskaya, 2011). The Manchurian pika inhabits the area between the Shilka and Argun rivers in Russia's Zabaikalskiy Territory, and mountain regions of the Greater and Lesser Khingan Ranges in China (Lissovsky et al., 


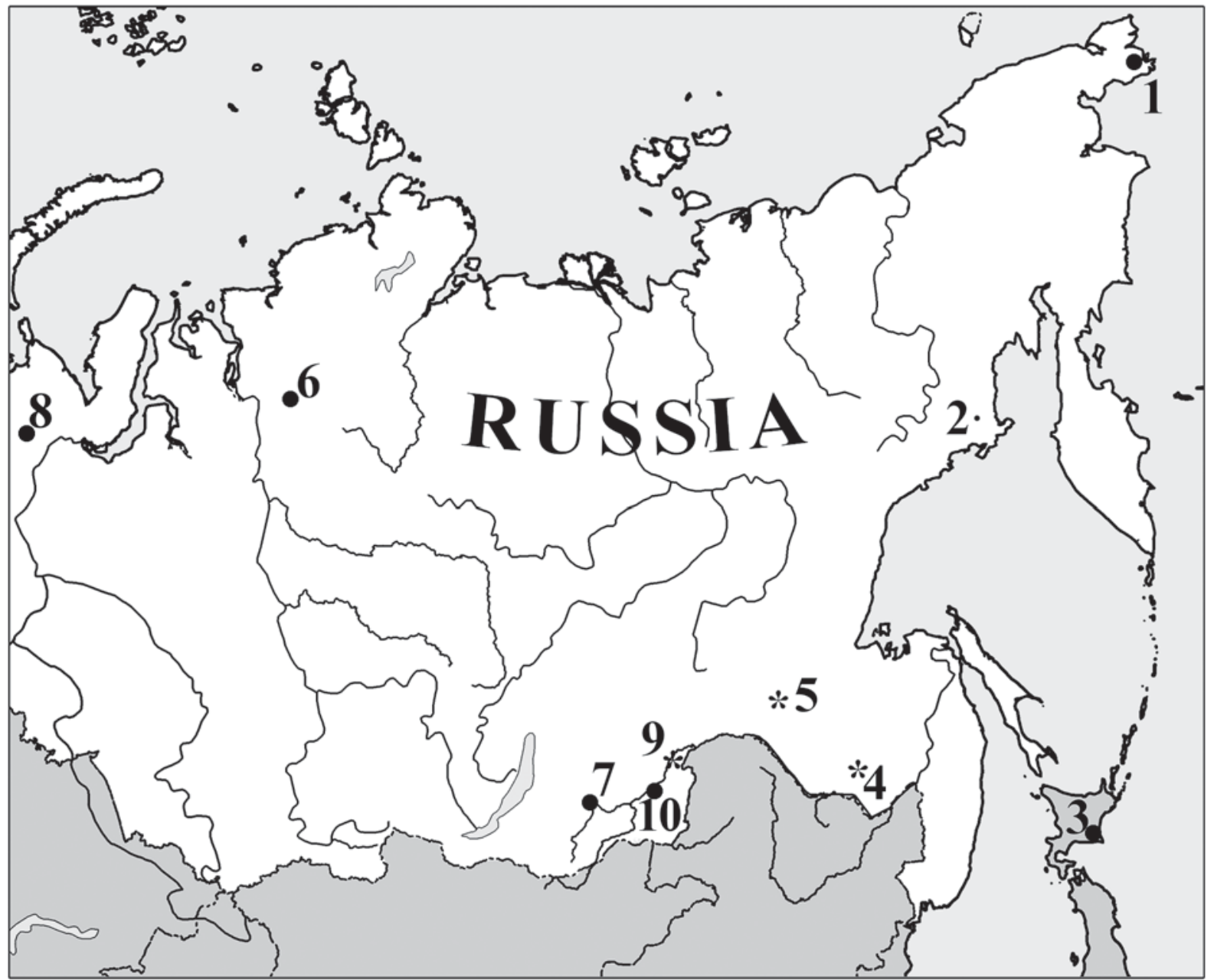

Fig. 1. Localities of pikas $O$. hyperborea and O. mantchurica that were studied kariologically. The numbers correspond to the numbers in Tab. 1. Localities we investigated are marked by asterisks.

2008; Lissovsky, 2015). This species was not found in the Russian part of Lesser Khingan Range. The two species have notable differences in their bioacoustical and mitochondrial DNA characteristics; morphological differences are slight (Lissovsky, 2005; Lissovsky et al., 2007, 2008).

The karyotypes of northern pikas had been studied from a few animals from the following localities (Tab. 1, Fig. 1): the Magadan Province (Vorontsov \& Ivanitskaya, 1973), Chukotka (Ivanitskaya, 1991), the Polar Urals (Vorontsov \& Ivanitskaya, 1973), the Zabaikalskiy Territory and Krasnoyarsk Territory (Putorana Plateau) (Formozov et al., 1999), as well as the Jewish Autonomous Region - Bastak Nature Reserve (Kartavtseva et al., 2014) in Russia; and Hokkaido Island in Japan (Hayata \& Shimba, 1969). The diploid chromosome number $(2 \mathrm{n}=40)$ was found for $O$. hyperborea in all studied populations. The X chromosome morphology was reported as subtelocentric for Northern pikas from most of the studied populations; however, it was defined as submetacentric for the specimen from the
Chukotka Peninsula (Ivanitskaya, 1991). Some differences between karyotypes of northern pikas from different geographical regions (the Krasnoyarsk and $\mathrm{Za}-$ baikalskiy territories and the Magadan Province) have been found by C-staining (Tab. 1). C-blocks were clearly visible on the first pair of metacentric chromosomes of pikas from the Putorana Plateau and the Zabaikalskiy Territory (Formozov et al., 1999). In contrast, animals from Magadan had no C-blocks on that chromosome pair (Ivanitskaya, 1991). Other pairs of autosomes had similar patterns of C-blocks in all studied animals. Nucleolar organizer regions (NORs) have been found on the four pairs of autosomes in O. hyperborea from the Krasnoyarsk and Zabaikalskiy territories (Formozov et al., 1999), but only on two pairs in pikas from the Magadan Province (Ivanitskaya, 1985).

The general morphology of karyotype and C- and Ag-NOR staining of $O$. mantchurica do not differ from O. hyperborea's (Formozov \& Baklushinskaya, 2011). The orderliness of information about karyotype structures in this group of pikas is somewhat destroyed with 


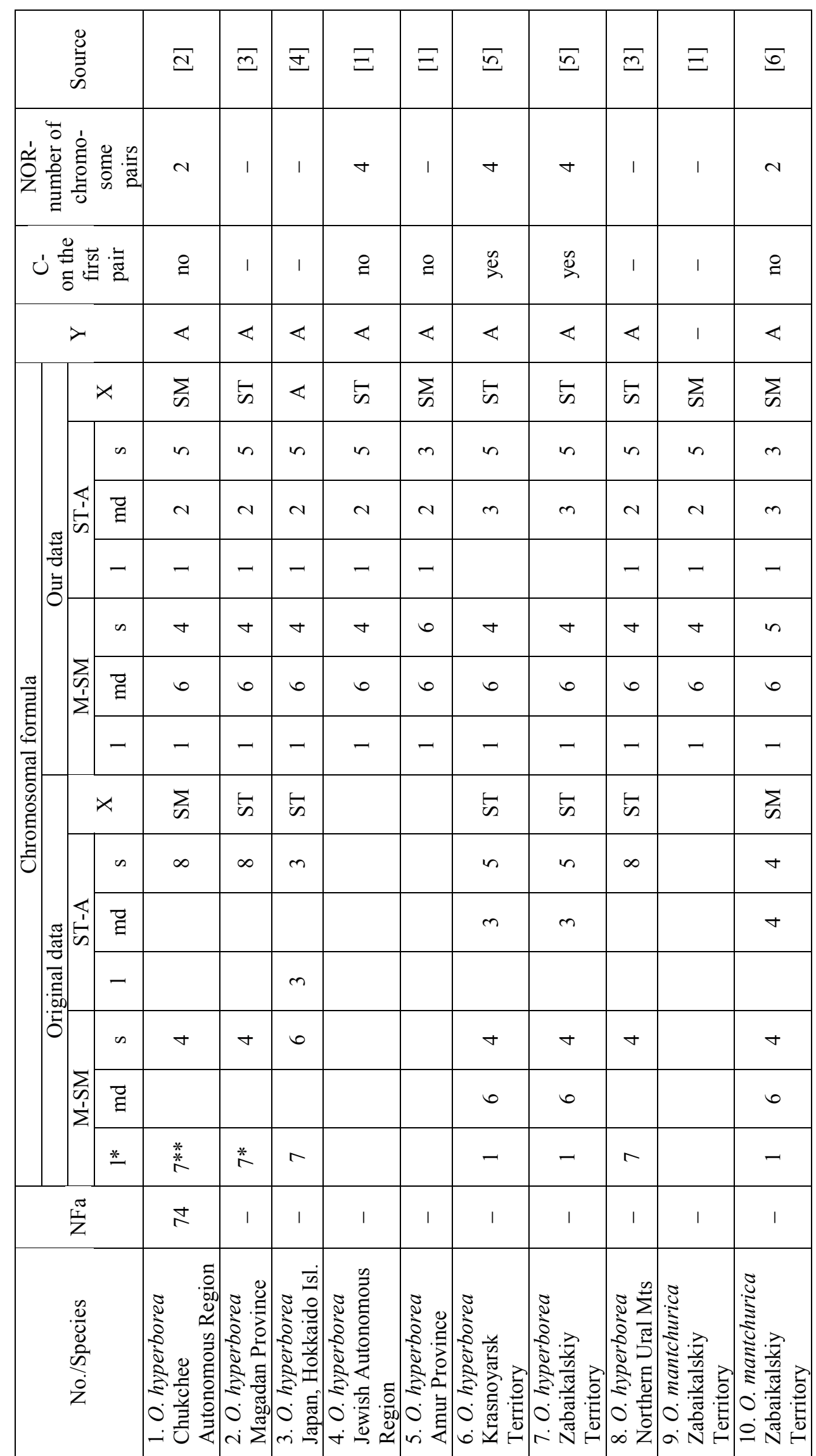




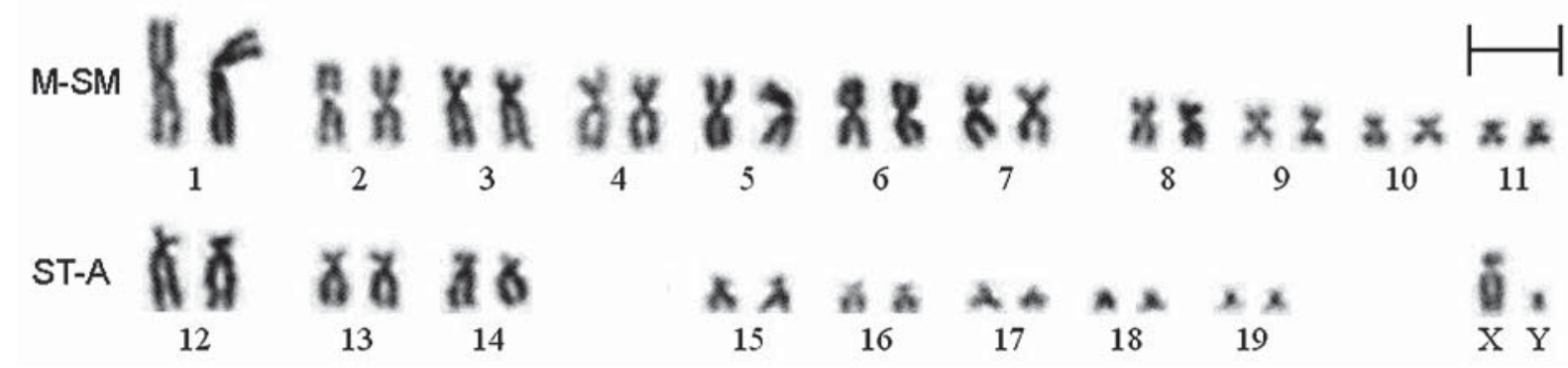

Fig. 2. The karyotype of northern pika Ochotona hyperborea \#2993 (male) from Bastak Nature Reserve, a routine staining, $2 \mathrm{n}=40$. M-SM - meta-submetacentric autosomes, ST-A — subtelo-acrocentric autosomes. Scale bar $=5 \mu \mathrm{m}$.

published information on one specimen of O. turuchanensis Naumov, 1934 from Southern Yakutia, identified by mtDNA (Formozov \& Baklushinskaya, 2011), with $2 \mathrm{n}=40$ as well (Formozov et al., 1999). Other specimens of $O$. turuchanensis from Putorana Plateau had $2 \mathrm{n}=42$ (Formozov et al., 1999).

We studied the karyotypes of $O$. hyperborea and $O$. mantchurica to develop cytogenetic diagnostics in pikas of the Amur River Basin. Besides, we describe a karyotype with $2 \mathrm{n}=39$ in O. mantchurica.

\section{Material and methods}

We studied karyotypes of six $O$. hyperborea specimens from two populations: the Bastak Nature Reserve in the Jewish Autonomous Region $\left(49.028^{\circ} \mathrm{N}, 133.073^{\circ}\right.$ E), \# 2993 (male), \#\# 2994-2997 (4 females) kept at the Institute of Biology and Soil Science, FEB RAS, Vladivostok; and the Soktahan Range, near the Rudenkina River mouth, Zeyskiy District, Amur Province $\left(53.429^{\circ} \mathrm{N}, 121.176^{\circ} \mathrm{E}\right.$ ), S-186423 (field \# 906) (male) kept in the Zoological Museum of Moscow State University. The specimen of $O$. mantchurica S-182047 (field \# 486) (female) from the right bank of the Shilka River, near the Barangon River mouth, Mogochinskiy District, Zabaikalskiy Territory $\left(53.4291^{\circ} \mathrm{N}, 121.1762^{\circ}\right.$ E) kept in the Zoological Museum of Moscow State University was also studied.

Cytological preparations were done from cells taken from the red marrow of the femur. A momentary tissue culture had been used for obtaining the metaphase chromosomes by Graphodatsky \& Radjabli's (1988) method. The living cells were washed out into Eagle Minimum Essential Medium with 20\% serum of cattle. The chromosomal preparations were made by standard method (Ford \& Hamerton, 1956). The simplified AgNOR technique was used to detect NORs (Howell \& Black, 1980). The differential C-staining (according to Sumner, 1972) was carried out for all specimens except $O$. mantchurica, which had insufficient volume of cellular material. No less than 20 metaphases were investigated for each animal.

We provisionally divided both our and published chromosomes into two groups (Tab. 1): meta-submetacentrics (M-SM) and subtelocentrics-acrocentrics (ST-
A). Each group was further divided into three subgroups: large, medium, and small. The subgroups were created to facilitate comparing our results with previously published data, as the authors did not adhere to any uniform scheme of the chromosome description.

The chromosomal preparations were analyzed with an AxioSkop 40* light microscope. The photographs were made using an AxioCamHR digital camera and the AXIOVISION 4.7 program (Carl Zeiss MicroImaging $\mathrm{GmbH}$, Germany). The work was conducted on the equipment at the Center of Collective Use "Biotechnology and Genetic Engineering" (Institute of Biology and Soil Science, FEB RAS, Vladivostok).

\section{Results}

Chromosomal sets of pikas from the Soktahan Range (Amur Province) and the Bastak Nature Reserve (Jewish Autonomous Region) each contained 40 chromosomes. The number of chromosome arms, NF=70-76, depends on the number of arms on the small ST-A pairs with varying degrees of spiralization. The karyotypes of pikas from the Bastak Nature Reserve contained 11 meta-submetacentric pairs (1 large, 6 medium, and 4 small) and 8 subtelo-acrocentric pairs (1 large, 2 medium and 5 small) of autosomes. The X chromosome was a medium-sized subtelocentric while the Y chromosome was a small acrocentric (Tab. 1, Fig. 2). The karyotype of pika from the Soktahan Range contained 13 meta-submetacentric pairs (1 large, 6 medium, and 6 small) and 6 subtelo-acrocentric pairs (1 large, 2 medium, and 3 small) of autosomes. The X chromosome was a medium-sized submetacentric while the Y chromosome was a small acrocentric (Fig. 3).

The pikas from the Bastak Nature Reserve and the Soktahan Range have NOR blocks in pericentromeric regions of four autosome pairs. In three of these pairs, NOR regions could be found in one or two homologues: one medium meta-submetacentric and two small meta-submetacentric; however, they are always present (Fig. 4A, B, "short arrows"). The fourth NOR region is localized in the pericentromeric region of the long arm of one of the homologues of the medium subtelocentric pair (Fig. 4B, "long arrow"). However, this NOR region had been irregular in different specimens. It was 


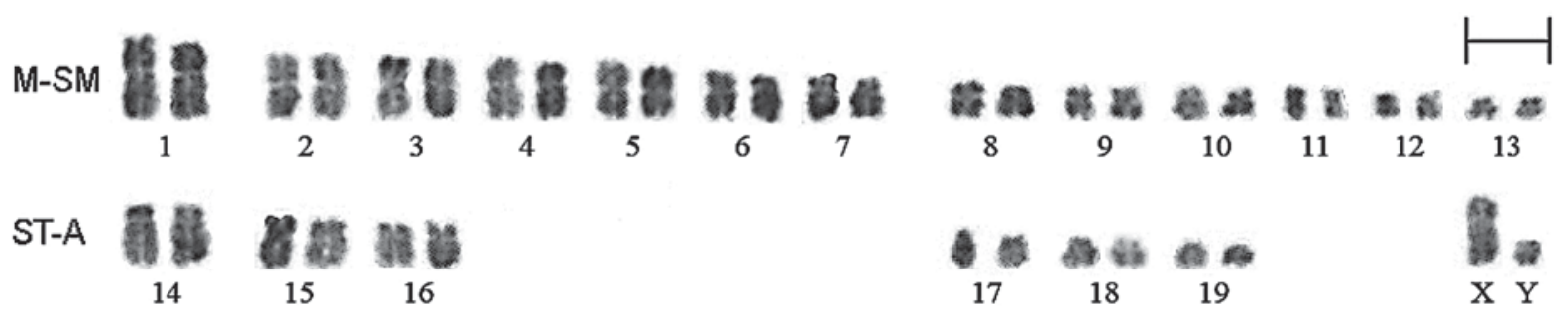

Fig. 3. The karyotype of northern pika Ochotona hyperborea S-186423 (male) from the Soktahan Range, a routine staining, $2 \mathrm{n}=40$. Abbreviations see fig. 2. Scale bar $=5 \mu \mathrm{m}$.

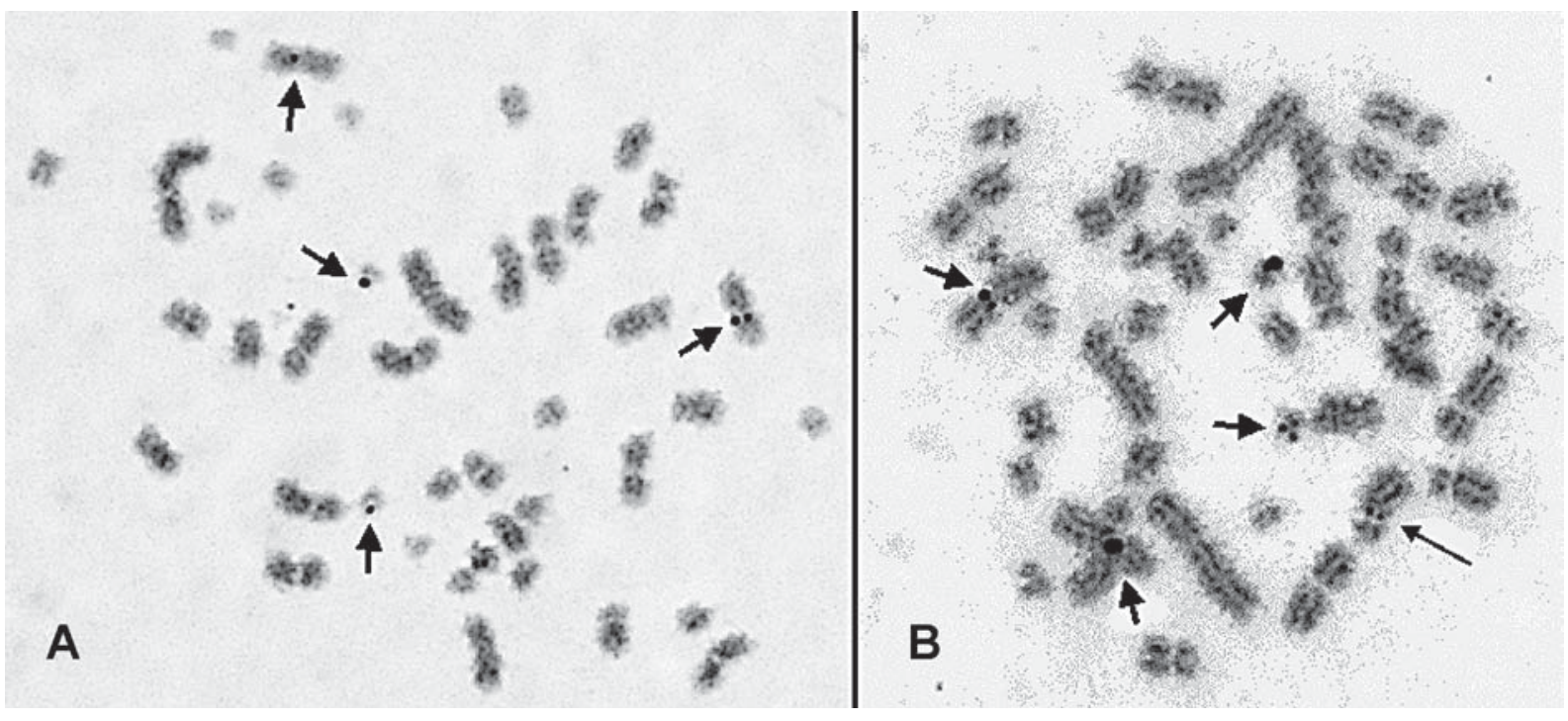

Fig. 4. The metaphase plates of northern pika Ochotona hyperborea \#2997 (female) from Bastak Nature Reserve, an Ag-NOR staining. A - meta-submetacentric chromosomes with NORs are marked with short arrows; B - NOR localized in pericentromeric region of the long arm of some of homologues of the medium subtelocentric pair is marked with a long arrow.

detected in no more than $19.6 \%$ of 66 chromosomal plates (Tab. 2). C-staining showed C-block absence on the first metacentric autosome pair of all northern pikas studied (Fig. 5).

The karyotype of the $O$. mantchurica female from the Zabaikalskiy Territory contained 39 chromosomes:

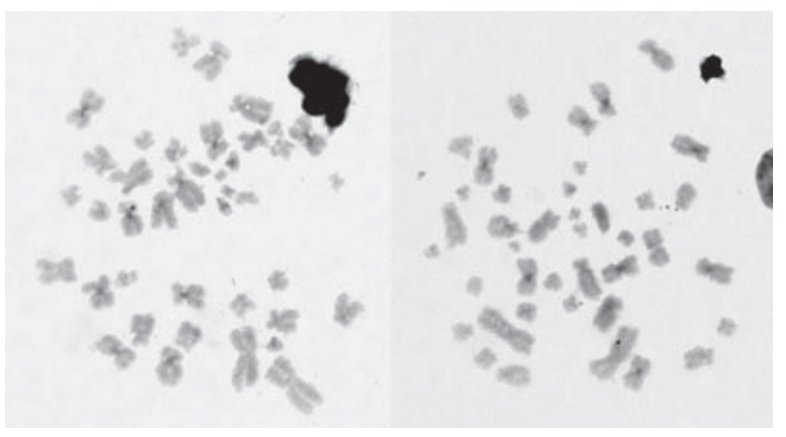

Fig. 5. The metaphase plates of northern pika Ochotona hyperborea \#2993 (male) from Bastak Nature Reserve, Cstaining. The largest metacentric pair lacks C-blocks in the pericentromeric region.
11 meta-submetacentric pairs (1 large, 6 medium, and 4 small) and 8 subtelo-acrocentric pairs ( 1 large, 2 medium, and 5 small) of autosomes. We investigated 21 metaphase plates, where 18 plates were with $2 n=39$ and three with $2 n=38$. The chromosomal set with $2 n=39$

Table 2. The number of metaphase plates with NOR region on the one homologue of the subtelocentric autosome pair for the pikas from the Bastak Nature Reserve.

\begin{tabular}{|l|c|c|c|}
\hline \multirow{2}{*}{ ID\# } & \multicolumn{3}{|c|}{ The number of metaphases studied: } \\
\cline { 2 - 4 } & $\begin{array}{c}\text { with NOR } \\
\text { blocks }\end{array}$ & $\begin{array}{c}\text { without } \\
\text { NOR blocks }\end{array}$ & Total \\
\hline 2993 & 0 & 3 & 3 \\
\hline 2994 & 5 & 5 & 10 \\
\hline 2995 & 3 & 19 & 21 \\
\hline 2996 & $1-2$ & $18-17$ & 19 \\
\hline 2997 & $2-3$ & $11-10$ & 13 \\
\hline Total & $11-13$ & $55-53$ & 66 \\
\hline
\end{tabular}




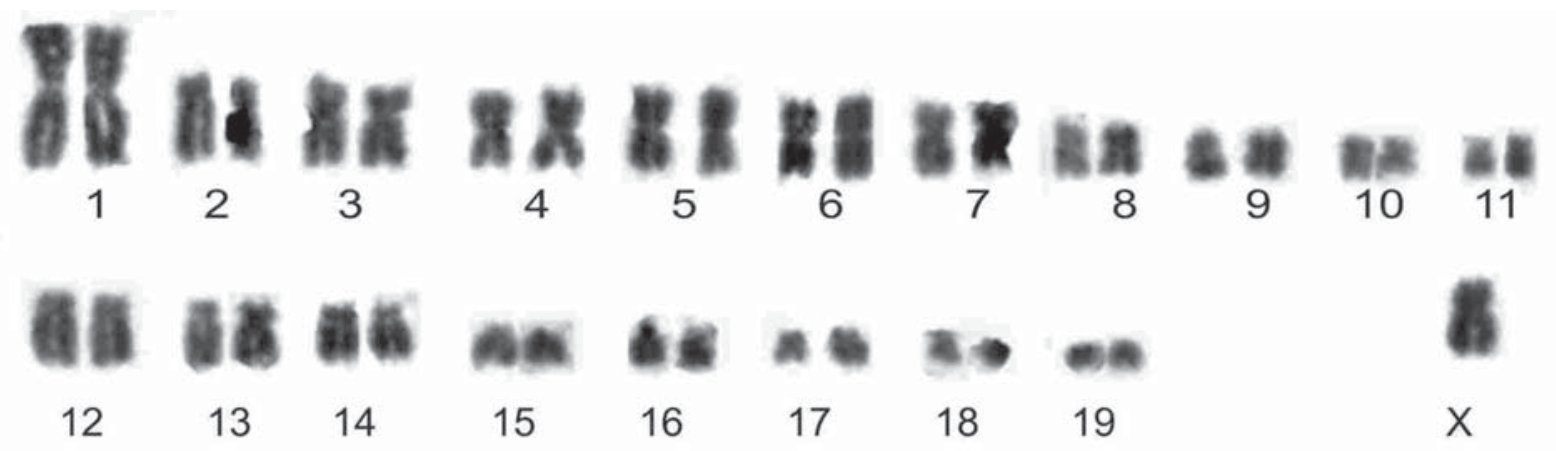

Fig. 6. The karyotype of northern pika Ochotona mantchurica S-182047 (female) from the Zabaikalskiy Territory, right bank of the Shilka River; a routine staining, 2n=39 (X0 variant).

had one meta-submetacentric of middle size without homologue. Therefore, we decided that the medium submeta-subtelocentric was the $\mathrm{X}$ chromosome and dealt with the X0 variant (Fig. 6).

\section{Discussion}

The karyotypes of $O$. hyperborea from the Bastak Nature Reserve do not differ from those of $O$. hyperborea from the Krasnoyarsk Territory in autosome morphology, number, or localization of NOR regions (Tab. $1)$. However, they differ in the C-staining of the first chromosome pair. The absence of the heterochromatic C-blocks on the first pair was previously found in karyotypes of pikas from the Magadan Province (Ivanitskaya, 1991). The pika from the Soktahan Range have different a formula of chromosomes (Tab. 1), but the same characteristics of C-staining with Bastak Nature Reserve and Magadan Province pikas.

The northern pikas from the Bastak Nature Reserve do not differ from $O$. hyperborea from the Putorana Plateau and Zabaikalskiy Territory by Ag-NOR staining. These pikas had the NOR regions on one submetacentric pair, one subtelocentric pair, and two small metacentric pairs of chromosomes (Formozov et al., 1999). Ivanitskaya (1985) only described the NOR regions on two small subtelocentric pairs in $O$. hyperborea from the Magadan Province. Thus, the pikas from the Magadan Province differ from other pikas in the number and localization of NOR regions in the chromosomes. Such polymorphism may indicate taxonomic differences of the investigated specimens or different activity of NOR regions in some pikas. Our investigation showed that activity of NOR regions in the medium-sized chromosomes of pikas from the Bastak Nature Reserve was absent in some metaphases (Tab. 2 ). Thus, we can speculate that activity of NOR regions in pikas from the Magadan Province could be low and these regions could be invisible at the moment of investigation.

Ochotona hyperborea and O. mantchurica have the same diploid chromosome number equal to 40 (Formo- zov \& Baklushinskaya, 2011). The female O. mantchurica that we studied had a diploid chromosome number equal to $39-\mathrm{X} 0$ variant, with morphology of the single $\mathrm{X}$ chromosome identified as submeta-subtelocentric. The X0 variant is not rare in mammals (Amleh et al., 2013), but it was found in pikas Ochotonidae for the first time.

There is some variation in the X chromosomes' morphology in both O. mantchurica and O. hyperborea. This chromosome was reported to be submetacentric in the previous study of $O$. mantchurica (Formozov \& Baklushinskaya, 2011); however, we found that it was submeta-subtelocentric. Similarly, it was reported as subtelocentric for O. hyperborea (Hayata \& Shimba, 1969; Vorontsov \& Ivanitskaya, 1973; Formozov et al., 1999) or submetacentric (Ivanitskaya, 1991; this study). Possibly, the difference in X chromosome morphology could be explained by different spiralization of chromosomes in the studied metaphases.

Morphology of autosomes of $O$. mantchurica does not differ from $O$. hyperborea. These species are phylogenetically close (Lissovsky et al., 2007, 2008; Kartavtseva et al., 2014). Therefore, we can speculate that the recent process of speciation was not accompanied by chromosomal rearrangements. The reported similarity of one specimen of $O$. turuchanensis to both species discussed above (Formozov \& Baklushinskaya, 2011) should be studied as well. This specimen was not studied using nuclear genes, and was collected not far from the known range of $O$. hyperborea. The hypothesis of mitochondrial introgression should be checked in the first place.

No variation of chromosome morphology was reported for northern pikas in the previous papers. However, we can state unusual proportion of meta-submetacentric and subtelo-acrocentric autosomes, as well as variable morphology of the X chromosome in O. hyperborea (Tab. 1). The northern pika has a vast range with deep geographical variation (Lissovsky et al., 2007). Such variation could be partially explained by subspecific structure. However, as we report the existence of variation in chromosome morphology and suppose variation in $\mathrm{C}$ - and NOR staining, the larger material should 
be studied to evaluate the extent of inter-population variation in various geographical locations.

ACKNOWLEDGEMENTS. This work was partially supported by the Russian Foundation for Basic Research under grants 07-04-10059, 09-04-10110 (field studies); the Far Eastern Branch of the Russian Academy of Sciences under grant 12-II-SB-06-018. The final preparation of the manuscript was supported by Russian Science Foundation, grant 14-50-00029. We sincerely thank the staff of the Zeyskiy and Bastak Nature Reserves for their help in organizing our fieldwork. We also thank the Microscopic Center of Institute of Biology and Soil Science for granting access to their microscopic equipment.

\section{References}

Amleh A., Xu B-Z. \& Taketo T. 2013. Role of sex chromosomes in mammalian female fertility // D'Aquino M. \& Stalone V. (eds.) Sex chromosome new research. New York: Nova Science Publishers Inc. P.53-86.

Ford C.E. \& Hamerton J.L. 1956. A colchicines hypotonic citrate squash sequence for mammalian chromosomes // Stain Technology. Vol.31. P.247-251.

Formozov N.A. \& Baklushinskaya I.Yu. 2011. [Manchurian pika (Ochotona mantchurica scorodumovi) from the interfluve of the Shilka and Argun rivers: karyotype and problems of pika taxonomy in Amurland and adjacent territories] // Zoologicheskii Zhurnal. Vol.90. No.4. P.490-497 [in Russian, with English summary].

Formozov N.A., Grigor'eva T.V. \& Surin V.L. 2006. [Molecular systematics of pikas of the subgenus Pika (Ochotona, Lagomorpha)] // Zoologicheskii Zhurnal. Vol.85. No.12. P.1465-1473 [in Russian, with English summary].

Formozov N.A., Lissovsky A.A. \& Baklushinskaya I.Yu. 1999. [Karyological diagnostics of pikas (Ochotona, Lagomorpha) from the Putorana Plateau] // Zoologicheskii Zhurnal. Vol.78. No.5. P.606-612 [in Russian, with English summary].

Graphodatsky A.S. \& Radjabli S.I. 1988. [The chromosomes of agricultural and laboratory mammals. An Atlas]. Novosibirsk: Nauka Press. 128 p. [in Russian].

Hayata I. \& Shimba H. 1969. A note on the somatic chromosomes of the Japanese pika, Ochotona hyperborea yesoensis Kishida // Journal of the Faculty of Science Hokkaido University. Series 6. Vol.17. No.2. P.393396.

Howell W.M. \& Black D.A. 1980. Controlled silver-staining of nucleolus organizer regions with a protective colloidal developer: a 1-step method // Experientia. Vol.36. P.1014-1015.

Ivanitskaya E.Yu. 1985. [Taxonomical and cytogenetical analysis of Transberingian relations of shrews (Sorex: Insectivora) and pikas (Ochotona: Lagomorpha)]. $\mathrm{PhD}$ thesis. Moscow University. Moscow. P.1-25 [in Russian].

Ivanitskaya E.Yu. 1991. [Comparative analysis of banded chromosomes of pikas and intrageneric taxonomy of the genus Ochotona (Ochotonidae, Lagomorpha)] // Proceedings of the Zoological Institute of the Russian Academy of Sciences. Vol.243. P.110-126 [in Russian, with English summary].

Kartavtseva I.V., Sheremetyeva I.N., Gus'kov V.Yu., Vakurin A.A., Kumaksheva E.V. \& Frisman L.V. 2014. [Taxonomic status of northern pika (Ochotona hyperborea) from the Sikhote-Alin] // Vestnik DVO RAN. Vol.2. P.79-85 [in Russian, with English summary].

Lissovsky A.A. 2005. [Comparative analyses of the vocalization of pikas (Ochotona, Mammalia) from alpinahyperborea group] // Bulletin Moskovskogo Obshchestva Ispytatelei Prirody, Otdel Biologicheskii. Vol.110. P.12-26 [in Russian, with English summary].

Lissovsky A.A. 2012. [Order Lagomorpha] // Pavlinov I.Ya. \& Lissovsky A.A. (eds.) The Mammals of Russia: A taxonomic and Geographic Reference. Moscow: KMK Scientific Press (Archive of the Zoological Museum of MSU. Vol.52). P.127-141 [in Russian].

Lissovsky A.A. 2015. A new subspecies of Manchurian pika Ochotona mantchurica (Lagomorpha, Ochotonidae) from the Lesser Khinggan Range, China // Russian Journal of Theriology. Vol.14. No.2. P.145-152.

Lissovsky A.A., Ivanova N.V. \& Borisenko A.V. 2007. Molecular phylogenetics and taxonomy of the subgenus Pika (Ochotona, Lagomorpha) // Journal of Mammalogy. Vol.88. No.5. P.1195-1204.

Lissovsky A.A., Yang Qisen \& Pil'nikov A.E. 2008. Taxonomy and distribution of the pikas (Ochotona, Lagomorpha) of alpina-hyperborea group in North-East China and adjacent territories // Russian Journal of Theriology. Vol.7. No.1. P.5-16.

Sokolov V.E., Ivanitskaya E.Yu., Gruzdev V.V. \& Heptner V.G. 1994. [Mammals of Russia and adjacent regions: Lagomorpha]. Moscow: Nauka Press. 272 p. [in Russian].

Sumner A.T. 1972. A simple technique for demonstraiting centrometric heterochromatin // Experimental Cell Research. Vol.83. P.438-442.

Vorontsov N.N. \& Ivanitskaya E.Yu. 1973. [Comparative karyology of north Palaearctic pikas (Ochotona, Lagomorpha, Ochotonidae)]// Zoologicheskii Zhurnal. Vol.52. No.4. P.584-588 [in Russian, with English summary]. 